\title{
EFIKASI PUPUK ORGANIK CAIR (POC) BUAH PEPAYA (Carica papaya L.) TERHADAP PRODUKTIVITAS TANAMAN MENTIMUN (Cucumis sativus L.)
}

\section{Efication Of Liquid Organic Fertilizer Pepaya Fruit (Carica Papaya L.) On The Productivity Of Flowering Plant (Cucumis Sativus L.)}

\author{
Rijalul Fikri Al Mubarok ${ }^{1}$ Bagus Tripama $^{2}$, Bejo Suroso ${ }^{3}$ \\ Program Studi Agroteknologi Fakultas Pertanian \\ Universitas Muhammadiyah Jember \\ e-mail : ${ }^{1}$ rijalulfikri309@gmail.com, ${ }^{2}$ midastripama30@gmail.com, \\ bejosuroso.jr@gmail.com
}

\begin{abstract}
ABSTRAK
Mentimun (Cucumis sativus L.) merupakan sayuran yang banyak dikonsumsi masyarakat karena merupakan sumber gizi, vitamin dan mineral yang dibutuhkan tubuh serta memiliki berbagai manfaat untuk kesehatan manusia, Tujuan penelitian untuk mengetahui pengaruh pemberian POC buah pepaya (Carica papaya L.) terhadap pertumbuhan dan produktivitas tanaman mentimun (Cucumis sativus L.). Penelitian dilaksanaan di Desa Kedungrejo, Kecamatan Rowokangkung, Kabupaten Lumajang. Waktu 3 bulan mulai Desember 2018 sampai Februari 2019, dengan ketinggian tempat +60 meter di atas permukaan laut. Rancangan yang digunakan rancangan Acak Kelompok Non Faktorial dengan satu faktor diulang 3 kali, yaitu dosis POC pepaya, terdiri dari 10 taraf yaitu P0 : Kontrol, P1 : 10ml/1, P2 : $20 \mathrm{ml} / \mathrm{l}, \mathrm{P} 3: 30 \mathrm{ml} / \mathrm{l}, \mathrm{P} 4: 40 \mathrm{ml} / \mathrm{l}$, P5 : 50ml/l, P6 : $60 \mathrm{ml} / \mathrm{l}, \mathrm{P} 7: 70 \mathrm{ml} / \mathrm{l}, \mathrm{P} 8$ : $80 \mathrm{ml} / \mathrm{l}, \mathrm{P} 9$ : $90 \mathrm{ml} / \mathrm{l}$. Hasil penelitian menunjukkan perlakuan dosis $\mathrm{POC}$ pepaya berpengaruh nyata pada variabel pengamatan tinggi tanaman umur $14 \mathrm{hst}$ dan panjang buah mentimun. Berpengaruh sangat nyata pada diameter buah, jumlah buah per tanaman, jumlah buah per plot, berat buah per tanaman, berat buah per plot. Tidak berpengaruh nyata pada, berat berangkasan basah, dan berat berangkasan kering tanaman mentimun.
\end{abstract}

Kata Kunci : POC, Dosis, Mentimun.

\begin{abstract}
Cucumber (Cucumis sativus L.) is a vegetable that is consumed by many people because it is a source of nutrition, vitamins and minerals needed by the body and has various benefits for human health.The aim of the study was to determine the effect of giving POC papaya fruit (Carica papaya L.) to the growth and productivity of cucumber plants (Cucumis sativus L.). The research was conducted in Kedungrejo Village, Rowokangkung Subdistrict, Lumajang Regency. 3 months from December 2018 to February 2019, with altitude of +60 meters above sea level.The design of the Non Factorial Randomized Group design with one factor was repeated 3 times, namely the dose of POC papaya, consisting of 10 levels, namely P0: Control, P1: $10 \mathrm{ml} / \mathrm{l}, \mathrm{P2:} 20 \mathrm{ml} / \mathrm{l}, \mathrm{P3}: 30 \mathrm{ml} / \mathrm{l}, \mathrm{P4}$ : $40 \mathrm{ml} /$ l, P5: 50ml /l, P6: $60 \mathrm{ml} / \mathrm{l}, \mathrm{P7:} 70 \mathrm{ml} / \mathrm{l}, \mathrm{P8:} 80 \mathrm{ml} / \mathrm{l}, \mathrm{P9:} 90 \mathrm{ml} / \mathrm{l}$.The results showed that the dosage of papaya POC had a significant effect on the observation variables of plant age 14 days and the length of cucumber fruit. Very significant effect on fruit diameter, number of fruits per plant, number of fruits per plot, fruit weight per plant, fruit weight per plot. There was no significant effect on the weight, wet weight and dry weight of cucumber plants.
\end{abstract}


Keywords: POC, Dosage, Cucumber.

\section{PENDAHULUAN}

Mentimun (Cucumis sativus L.) merupakan sayuran buah yang banyak dikonsumsi masyarakat karena merupakan sumber gizi, vitamin dan mineral yang dibutuhkan tubuh serta memiliki berbagai manfaat untuk kesehatan tubuh, terutama dapat menurunkan tekanan darah. Oleh karena itu, mentimun tidak hanya dimanfaatkan untuk konsumsi segar melainkan juga digunakan sebagai bahan baku industri kosmetik dan obat-obatan. Kebutuhan dan permintaan komoditas mentimun akan semakin meningkat sejalan dengan peningkatan jumlah penduduk dan konsumsi mentimun baik untuk konsumsi segar maupun untuk bahan baku industri kosmetik dan obat (Oktaviana dkk., 2016).

Keunggulan yang dimiliki mentimun tidak diimbangi dengan tingkat produksinya. Menurut data dari Departemen Pertanian Indonesia tahun 2014, produksi mentimun mengalami penurunan pada setiap tahunnya. Produksi mentimun tahun 2009 sebesar 583.13 ton/Ha, sedang pada tahun 2014 sebesar 477,97 ton/Ha Badan Pusat Statistik (2014).

Hal ini disebabkan oleh kesuburan tanah yang terus menurun serta penerapan teknik budidaya yang kurang tepat. Kandungan bahan organik dalam tanah terus merosot akibat penggunaan pupuk kimia yang berlebihan (Musnamar,2003). Menurut Roidah (2013) penggunaan pupuk kimia yang berlebihan berdampak terhadap penurunan kualitas lingkungan dan kesehatan manusia serta dapat membuat unsur hara tanah semakin menurun. Mentimun sebagai tanaman semusim membutuhkan N, P dan K dalam jumlah relatif besar dan untuk mendapatkan hasil mentimun yang tinggi diperlukan unsur hara dalam jumlah yang cukup dan seimbang (Tufaila, 2014). Salah satu usaha untuk meningkatkan kesuburan tanah, selain sifat fisika dan kimia tanahnya perlu dilakukan dengan perbaikan sifat biologinya. Salah satu caranya dapat dilakukan dengan memanfaatkan Pupuk Organik Cair yang disingkat POC.

Pupuk organik cair selain dapat memperbaiki sifat fisik, kimia dan biologi tanah dapat membantu meningkatkan produksi tanaman, meningkatkan kualitas produk tanaman, mengurangi penggunaan pupuk anorganik dan sebagai alternatif pengganti pupuk kandang (Indrakusuma, 2000). Pada umumnya bahan baku POC adalah berbagai sumber daya yang tersedia disekitar lingkungan, seperti nasi, bonggol pisang, urine sapi, limbah buah-buahan, limbah sayuran dan lain-lain. Bahan bahan tersebut merupakan tempat yang disukai oleh mikroorganisme sebagai media untuk hidup dan 
berkembangnya mikroorganisme yang berguna dalam mempercepat penghancuran bahanbahan organik atau sebagai tambahan nutrisi bagi tanaman (Purwasasmita, 2009). Selain sumberdaya di atas, sumber daya yang dapat dijadikan bahan baku POC dan mudah didapat adalah pepaya.

Mikroorganisme yang terkandung dalam POC pepaya dapat merubah unsur hara yang tersedia menjadi bentuk yang lebih mudah diserap tanaman. Hal ini sesuai dengan pendapat Arinong (2014) mikroorganisme dalam tanah merangsang proses dekomposisi media sehingga membantu penyediaan hara dari bahan organik yang tersedia dalam tanah dan akhirnya dapat meningkatan penyerapan hara oleh tanaman, sehingga tanaman lebih baik pertumbuhannya.

Pepaya merupakan tumbuhan yang banyak dijumpai di lingkungan sekitar. Pepaya merupakan salah satu komoditas buah yang hampir semua bagiannya dapat dimanfaatkan. Buah pepaya mengandung karbohidrat, kalsium, magnesium, potasium, dan posfor yang tinggi (Suketi, 2010). Kandungan tersebut sangat baik untuk pertumbuhan dan perkembangan mikroorganisme dan tanaman.

Karena melihat sebagian besar petani di Indonesia masih banyak menggunakan pupuk kimia untuk meningkatkan produktivitas tanaman mentimun, namun memiliki dampak yang negatif bagi lingkungan dan kesehatan. Maka perlu dilakukan penelitian tentang Efikasi pupuk organik cair (POC) buah pepaya terhadap produktivitas tanaman mentimun.

\section{METODE PENELITIAN}

Penelitian dilaksanakan di Desa Kedungrejo, Kecamatan Rowokangkung, Kabupaten Lumajang. Pada bulan Desember 2018 sampai Februari 2019, ketinggian tempat sekitar +60 meter di atas permukaan laut. Penelitian ini menggunakan Rancangan Acak Kelompok (RAK) Non Faktorial dengan satu faktor diulang 3 kali yaitu dosis POC buah pepaya yang terdiri dari 10 taraf yaitu P0 : Kontrol, P1 : 10ml/1, P2 : 20 ml/1, P3 : 30 ml/l, P4 : 40 ml/l, P5 : 50ml/l, P6 : 60 ml/l, P7 : 70 ml/l, P8 : 80 ml/l, P9 : 90 ml/l.

\section{HASIL DAN PEMBAHASAN}

\section{Tinggi Tanaman Mentimun Umur 14 dan 21 HST (cm)}

Hasil analisis ragam menunjukkan perlakuan dosis POC buah pepaya berpengaruh nyata pada tinggi tanaman mentimun umur $14 \mathrm{hst}$, tetapi tidak berpengaruh nyata pada tinggi tanaman mentimun umur 21 hst Perlakuan yang memberikan pengaruh nyata atau sangat nyata maka dilanjutkan dengan uji jarak berganda Duncan (Tabel 1). 
Tabel 1. Pengaruh dosis POC buah pepaya terhadap tinggi tanaman mentimun 14 hst.

\begin{tabular}{lc}
\hline Dosis POC & $\begin{array}{c}\text { Rata-Rata Tinggi Tanaman } \\
(\mathrm{cm})\end{array}$ \\
\hline (P0) Tanpa POC Pepaya & $22,93 \mathrm{c}$ \\
(P1) POC Pepaya dosis $10 \mathrm{ml} / 1$ Air & $23,53 \mathrm{c}$ \\
(P2) POC Pepaya dosis $20 \mathrm{ml} / 1$ Air & $23,80 \mathrm{bc}$ \\
(P3) POC Pepaya dosis $30 \mathrm{ml} / 1$ Air & $23,93 \mathrm{bc}$ \\
(P4) POC Pepaya dosis $40 \mathrm{ml} / 1$ Air & $23,42 \mathrm{c}$ \\
(P5) POC Pepaya dosis $50 \mathrm{ml} / 1$ Air & $24,38 \mathrm{bc}$ \\
(P6) POC Pepaya dosis $60 \mathrm{ml} / 1$ Air & $24,61 \mathrm{abc}$ \\
(P7) POC Pepaya dosis $70 \mathrm{ml} / 1$ Air & $24,64 \mathrm{abc}$ \\
(P8) POC Pepaya dosis $80 \mathrm{ml} / 1$ Air & $26,69 \mathrm{ab}$ \\
(P9) POC Pepaya dosis $90 \mathrm{ml} / 1$ Air & $27,34 \mathrm{a}$ \\
\hline
\end{tabular}

Keterangan : Angka-angka yang diikuti huruf sama menunjukkan tidak berbeda nyata pada Uji jarak berganda Duncan taraf 5\%

Berdasarkan Tabel 1, hasil uji jarak berganda Duncan taraf 5\% terhadap variabel pengamatan tinggi tanaman 14 hst menunjukkan bahwa perlakuan P4 (pemberian POC buah pepaya dosis $40 \mathrm{ml} / \mathrm{l}$ air) berbeda nyata dengan perlakuan P9 (pemberian POC buah pepaya dosis $90 \mathrm{ml} / \mathrm{l}$ air) dan P8 (pemberian POC buah pepaya dosis $80 \mathrm{ml} / \mathrm{l}$ air), tetapi tidak berbeda nyata dengan perlakuan lainnya. Sedangkan perlakuan P9 (pemberian POC buah pepaya dosis $90 \mathrm{ml} / \mathrm{l}$ air) tidak berbeda nyata dengn perlakuan P8 (pemberian POC buah pepaya dosis $80 \mathrm{ml} / \mathrm{l}$ air) tetapi berbeda nyata dengan perlakuan lainnya. Rata-rata tinggi tanaman tertinggi didapat pada perlakuan P9 (pemberian POC buah pepaya dosis $90 \mathrm{ml} / \mathrm{l}$ air) yaitu $27,34 \mathrm{~cm}$.

Pemberian POC buah pepaya diduga dapat memperbaiki kondisi sifat fisik tanah. Mikroba yang terkandung dalam POC buah pepaya dapat merubah unsur hara yang tersedia menjadi bentuk yang lebih mudah diserap tanaman. Hal ini sesuai dengan pendapat Arinong (2014) mikroba dalam tanah merangsang proses dekomposisi media sehingga membantu penyediaan hara dari bahan organik yang tersedia dalam tanah dan akhirnya dapat meningkatan penyerapan hara oleh tanaman, sehingga tanaman lebih baik pertumbuhannya. Azotobacter sp dan Azosprillium sp merupakan bakteri penambat nitrogen yang memiliki kemampuan dalam meningkatkan maupun memperbaiki kandungan unsur nitrogen dalam tanah. Selain itu mikroba tersebut mampu menghasilkan substansi zat pemacu pertumbuhan seperti IAA yang dapat meningkatkan pertumbuhan tanaman (Ananty, 2008). 


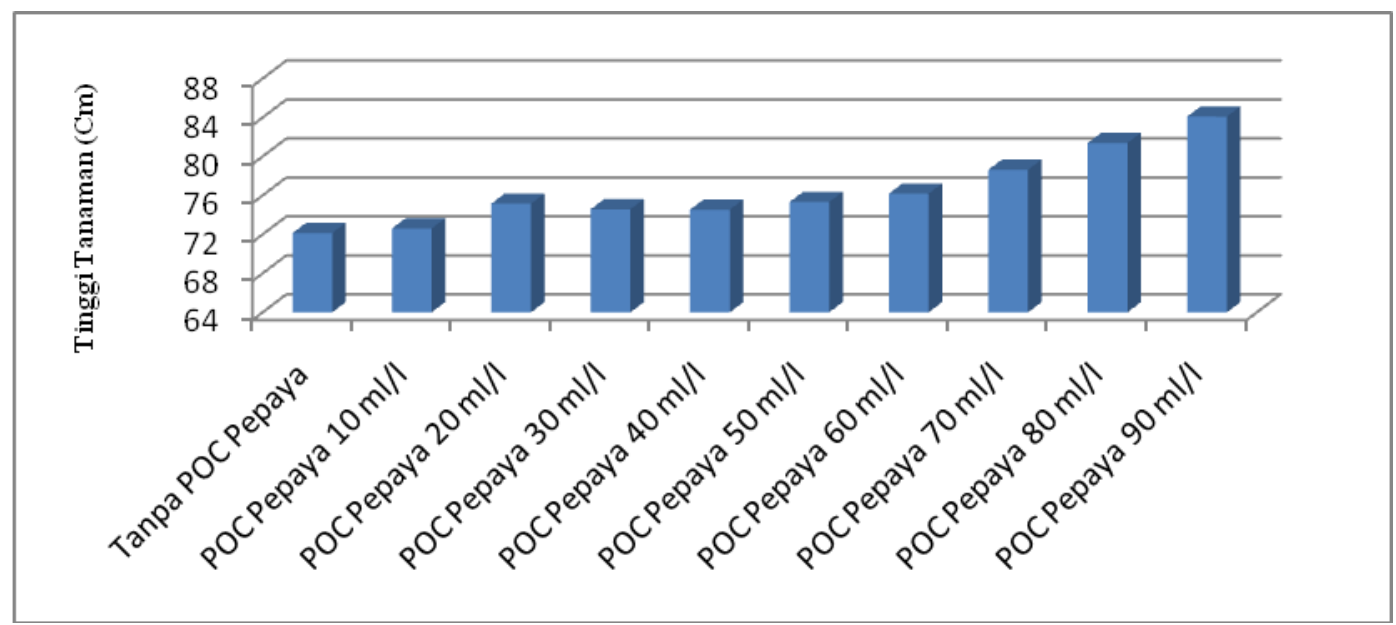

Gambar 1. Pengaruh dosis POC buah pepaya terhadap tinggi tanaman mentimun umur 21 hst.

Gambar 1, menunjukkan bahwa perlakuan dosis POC buah pepaya tidak memberikan pengaruh nyata terhadap tinggi tanaman umur 21 hst. Perlakuan yang memberikan rata-rata tinggi tanaman tertinggi pada 21 hst yaitu P9 (pemberian POC buah pepaya dosis $90 \mathrm{ml} / \mathrm{l}$ air) $84,09 \mathrm{~cm}$. Hal ini diduga karena perbedaan dosis POC buah pepaya. Semakin tinggi dosis yang diberikan maka semakin banyak mikroorganisme lokal yang terkandung, sehingga dapat memperbaiki kondisi unsur $\mathrm{N}$ dalam tanah penelitian yang rendah.

Menurut Syaifudin (2010), POC buah-buahan mengandung bakteri pemicu pertumbuhan tanaman dan bakteri lain yang akan membantu meningkatkan fiksasi nitrogen bebas. Nitrogen sangat penting dalam tumbuhan karena nitrogen berfungsi untuk meningkatkan pertumbuhan tanaman.

Penambahan pupuk hayati dapat meningkatkan kandungan $\mathrm{N}$ dalam tanah. Mikroba penambat $\mathrm{N}$ yaitu Azotobacter sp. dapat membantu menyediakan $\mathrm{N}$ bagi tanaman. Proses fiksasi $\mathrm{N}_{2}$ yang dilakukan Azotobacter sp menggunakan enzim nitrogenase (terdiri dari dua jenis protein, yaitu protein $\mathrm{Fe}$ dan $\mathrm{Fe}-\mathrm{Mo}$ ) dengan bantuan ATP sebagai energi (Husnaeni, dkk 2018).

\section{Panjang Buah Mentimun (cm)}

Hasil analisis ragam menunjukkan perlakuan dosis POC buah pepaya berpengaruh nyata pada variabel pengamatan panjang buah mentimun. Perlakuan yang memberikan pengaruh nyata atau sangat nyata maka dilanjutkan dengan uji jarak berganda Duncan (Tabel 2). 
Tabel 2. Pengaruh dosis POC buah Pepaya terhadap panjang buah tanaman mentimun.

\begin{tabular}{lc}
\hline \multicolumn{1}{c}{ Dosis POC } & $\begin{array}{c}\text { Rata-Rata Panjang } \\
\text { Buah }(\mathrm{Cm})\end{array}$ \\
\hline (P0) Tanpa POC Pepaya & $22,51 \mathrm{c}$ \\
(P1) POC Pepaya dosis $10 \mathrm{ml} / 1$ Air & $22,82 \mathrm{bc}$ \\
(P2) POC Pepaya dosis $20 \mathrm{ml} / 1$ Air & $23,31 \mathrm{bc}$ \\
(P3) POC Pepaya dosis $30 \mathrm{ml} / 1$ Air & $23,09 \mathrm{bc}$ \\
(P4) POC Pepaya dosis $40 \mathrm{ml} / 1$ Air & $23,23 \mathrm{bc}$ \\
(P5) POC Pepaya dosis $50 \mathrm{ml} / 1$ Air & $23,30 \mathrm{bc}$ \\
(P6) POC Pepaya dosis $60 \mathrm{ml} / 1$ Air & $23,38 \mathrm{~b}$ \\
(P7) POC Pepaya dosis $70 \mathrm{ml} / 1$ Air & $23,36 \mathrm{bc}$ \\
(P8) POC Pepaya dosis $80 \mathrm{ml} / 1$ Air & $23,55 \mathrm{ab}$ \\
(P9) POC Pepaya dosis $90 \mathrm{ml} / 1$ Air & $24,27 \mathrm{a}$ \\
\hline
\end{tabular}

Keterangan : Angka-angka yang diikuti huruf sama menunjukkan tidak berbeda nyata pada Uji jarak berganda Duncan taraf 5\%.

Berdasarkan Tabel 2, hasil uji jarak berganda Duncan taraf 5\% terhadap variabel pengamatan panjang buah menunjukkan perlakuan P0 (tanpa pemberian POC buah pepaya) berbeda nyata dengan perlakuan P6 (pemberian POC buah pepaya dosis $60 \mathrm{ml} / \mathrm{l}$ air), perlakuan P8 (pemberian POC buah pepaya dosis $80 \mathrm{ml} / \mathrm{l}$ air) dan perlakuan P9 (pemberian POC buah pepaya dosis $90 \mathrm{ml} / \mathrm{l}$ air) tetapi tidak berbeda nyata dengan perlakuan lainnya. Perlakuan P6 (pemberian POC buah pepaya dosis $60 \mathrm{ml} / \mathrm{l}$ air) berbeda nyata dengan perlakuan P9 (pemberian POC buah pepaya dosis $90 \mathrm{ml} / \mathrm{l}$ air) dan perlakuan P0 (tanpa pemberian POC buah pepaya) tetapi tidak berbeda nyata dengan perlakuan lainnya. Sedangkan perlakuan P9 (pemberian POC buah pepaya dosis $90 \mathrm{ml} / \mathrm{l}$ air) tidak berbeda nyata dengan perlakuan P8 (pemberian POC buah pepaya dosis $80 \mathrm{ml} / \mathrm{l}$ air) tetapi berbeda nyata dengan perlakuan lainnya. Rata-rata panjang buah terpanjang dihasilkan pada perlakuan P9 (pemberian POC buah pepaya dosis $90 \mathrm{ml} / \mathrm{l}$ air) yaitu 24,27 $\mathrm{cm}$. Hal ini diduga dengan pemberian POC buah pepaya dapat memperbaiki sifat fisik tanah sehingga tanaman dapat tumbuh dengan baik dan menghasilkan buah yang maksimal.

Kondisi unsur hara dalam tanah peneltian yang cukup rendah yaitu $\mathrm{N}=0,166 \%$, $\mathrm{P}=1,858 \mathrm{ppm}, \mathrm{K}=3,230 \mathrm{ppm}$ dan $\mathrm{C}$-Organik = 1,332\% (Laboratorium Tanah Politeknik Negeri Jember) mengindikasikan bahwa tanah tersebut miskin nutrisi dan akan mempengaruhi pertumbuhan dan produktivitas tanaman. Dengan pemberian POC buah pepaya diharapkan meningkatkan nutrisi yang dibutuhkan tanaman.

Tersedianya mikroba di dalam tanah dapat meningkatkan aktivitas di dalam tanah sehingga perombakan bahan organik menjadi senyawa kompleks yang dibutuhkan mentimun untuk tumbuh, berkembang, dan menghasilkan produk secara maksimal. Yadi dkk (2012) menyatakan bahwa, mikroba berperan positif dalam menyediakan unsur hara 
bagi tanaman yang mengakibatkan buah mentimun menjadi lebih panjang dari panjang buah yang sesungguhnya.

Didalam POC buah pepaya mengandung mikroba Actinomycetes bakteri pelarut fosfat dan bakteri selulotik (Kusmiadi, 2015). Mikroba pelarut fosfat terdiri dari bakteri dan fungi seperti : Bacillus polymyxa, Pseudomonas sp., Aspergilus awamouri, dan Penicillium sp. yang diidentifikasi dapat melarutkan bentuk $\mathrm{P}$ menjadi $\mathrm{PO}_{4-}$ yang dapat dimanfaatkan tanaman dalam meningkatkan pertumbuhan dan produksi (Widyati, 2013).

Fitriatin (2009), bakteri Pseudomonas sp dan fungi Penicillium sp bekerja secara sinergis mengeluarkan enzim fosfatase dalam proses mineralisasi dan imobilisasi untuk mengubah $\mathrm{P}$ organik menjadi $\mathrm{P}$ anorganik. Kesinergisan tersebut membantu menyediakan P bagi tanaman padi gogo sehingga pengisian bulir-bulir padi meningkat. Bakteri Pseudomonas sp dan fungi Penicillium sp dapat mensubstitusi sebagian atau keseluruhan kebutuhan tanaman akan unsur P. Bakteri ini memiliki potensi yang sama dengan pupuk TSP dalam menyediakan unsur $\mathrm{P}$ untuk diserap tanaman.

\section{Diameter Buah Mentimun (cm)}

Hasil analisis ragam menunjukkan perlakuan dosis POC buah pepaya berpengaruh sangat nyata pada variabel pengamatan diameter buah mentimun. Perlakuan yang memberikan pengaruh nyata atau sangat nyata maka dilanjutkan dengan uji jarak berganda Duncan (Tabel 3).

Tabel 3. Pengaruh dosis POC buah Pepaya terhadap diameter buah mentimun.

\begin{tabular}{cc}
\hline Dosis POC & $\begin{array}{c}\text { Rata-Rata Diameter Buah } \\
\text { Mentimun }(\mathrm{cm})\end{array}$ \\
\hline (P0) Tanpa POC Pepaya & $4,87 \mathrm{c}$ \\
(P1) POC Pepaya dosis 10 ml/1 Air & $4,89 \mathrm{bc}$ \\
(P2) POC Pepaya dosis 20 ml/1 Air & $4,90 \mathrm{bc}$ \\
(P3) POC Pepaya dosis 30 ml/1 Air & $4,91 \mathrm{bc}$ \\
(P4) POC Pepaya dosis 40 ml/1 Air & $4,91 \mathrm{bc}$ \\
(P5) POC Pepaya dosis $50 \mathrm{ml} / 1$ Air & $4,93 \mathrm{bc}$ \\
(P6) POC Pepaya dosis 60 ml/1 Air & $4,92 \mathrm{bc}$ \\
(P7) POC Pepaya dosis $70 \mathrm{ml} / 1$ Air & $4,93 \mathrm{bc}$ \\
(P8) POC Pepaya dosis $80 \mathrm{ml} / 1$ Air & $4,95 \mathrm{~b}$ \\
(P9) POC Pepaya dosis $90 \mathrm{ml} / 1$ Air & 5,01 a \\
Keterangan : Angka-angka yang diikuti huruf sama menunjukkan tidak berbeda nyata pada Uji \\
jarak berganda Duncan taraf 5\%
\end{tabular}


buah pepaya dosis $80 \mathrm{ml} / \mathrm{l}$ air) berbeda nyata dengan perlakuan P9 (pemberian POC buah pepaya dosis $90 \mathrm{ml} / \mathrm{l}$ air) dan perlakuan P0 (tanpa pemberian POC buah pepaya), tetapi tidak berbeda nyata dengan perlakuan lainnya. Sedangkan perlakuan P9 (pemberian POC buah pepaya dosis $90 \mathrm{ml} / \mathrm{l}$ air) sangat berbeda nyata dengan perlakuan lainnya. Rata-rata diameter terbaik dihasilkan pada perlakuan P9 (pemberian POC buah pepaya dosis $90 \mathrm{ml} / \mathrm{l}$ air) yaitu $5,01 \mathrm{~cm}$. Hal ini diduga pemberian POC buah pepaya dapat menambah jumlah populasi mikroba dalam tanah. Akan meningkatkan jumlah unsur hara yang berasal dari POC dan penguraian bahan organik tanah oleh mikroba, sehingga tanaman lebih mudah menyerap unsur hara dan pertumbuhan buah lebih maksimal.

Mikroorganisme memiliki peran penting bagi kesuburan tanah, karena bahan organik dari sisa-sisa tanaman dapat didekomposisikan menjadi humus dan diuraikan menjadi sumber unsur hara yang dibutuhkan bagi tanaman. Maida (2013) menyatakan bahwa, aktivitas mikroorganisme di dalam tanah juga menghasilkan hormon-hormon pertumbuhan seperti : auksin, giberillin dan sitokinin yang dapat memacu pertumbuhan dan perkembangan akar-akar rambut sehingga daerah pencarian unsur-unsur hara semakin luas.

POC buah pepaya juga mengandung hormon yang memacu pertumbuhan dan perkembangan tanaman. Hormon tersebut salah satunya yaitu auksin, auksin mampu memacu pertumbuhan dan perkembangan tanaman sehingga dapat memberikan pengaruh yang lebih baik terhadap produksi tanaman mentimun. Pemberian POC buah pepaya dapat meningkatkan diameter buah mentimun. Hal ini berhubungan dengan hormon auksin yang terkandung dalam POC buah pepaya dalam meningkatkan diameter buah. Dewi (2008) menyatakan bahwa, auksin dapat meningkatkan pertumbuhan, diferensiasi, percabangan akar serta perkembangan buah. Auksin memiliki peran utama dalam memompa proton membran plasma. Auksin menstimulasi pemompaan proton membran plasma, sehingga akan meningkatkan potensial membran dan menurunkan $\mathrm{pH}$ didalam dinding sel. Hal tersebut akan meningkatkan penyerapan ion kedalam sel yang diikuti oleh penyerapan air secara osmosis, sehingga memungkinkan sel pada bagian tanaman bertambah panjang atau besar.

\section{Jumlah Buah Mentimun Per Tanaman}

Hasil analisis ragam perlakuan dosis POC buah pepaya berpengaruh sangat nyata pada variabel pengamatan jumlah buah per tanaman mentimun. Perlakuan yang memberikan pengaruh nyata atau sangat nyata maka dilanjutkan dengan uji jarak berganda Duncan (Tabel 4). 
Tabel 4. Pengaruh dosis POC buah Pepaya terhadap jumlah buah per tanaman mentimun.

\begin{tabular}{lc}
\hline Perlakuan & Rata-Rata Jumlah Buah Per \\
Tanaman
\end{tabular}

Keterangan : Angka-angka yang diikuti huruf sama menunjukkan tidak berbeda nyata pada Uji jarak berganda Duncan taraf 5\%

Berdasarkan Tabel 4, hasil uji jarak berganda Duncan taraf 5\% terhadap variabel pengamatan jumlah buah per tanaman menunjukkan bahwa perlakuan P3 (pemberian POC buah pepaya dosis $30 \mathrm{ml} / 1$ air) sangat berbeda nyata dengan perlakuan P9 (pemberian POC buah pepaya dosis $90 \mathrm{ml} / \mathrm{l}$ air), P8 (pemberian POC buah pepaya dosis $80 \mathrm{ml} / \mathrm{l}$ air) dan P6 (pemberian POC buah pepaya dosis $60 \mathrm{ml} / \mathrm{l}$ air), tetapi tidak berbeda nyata dengan perlakuan lainnya. Sedangkan P9 (pemberian POC buah pepaya dosis 90 $\mathrm{ml} / \mathrm{l}$ air) tidak berbeda nyata dengan perlakuan P6 (pemberian POC buah pepaya dosis 60 $\mathrm{ml} / \mathrm{l}$ air) dan P8 (pemberian POC buah pepaya dosis $80 \mathrm{ml} / \mathrm{l}$ air), tetapi sangat berbeda nyata dengan perlakuan lainnya Hasil rata-rata buah terbanyak dihasilkan pada perlakuan P9 (pemberian POC buah pepaya dosis $90 \mathrm{ml} / \mathrm{l}$ air) yaitu 20 buah.

Hal ini diduga mikroba yang terkandung dalam POC buah pepaya meningkatkan penguraian bahan organik didalam tanah sehingga menjadi tersedia bagi tanaman mentimun. Semakin tinggi dosis yang diberikan semakin banyak pula jumlah mikroorganisme yang berperan terhadap penguraian bahan-bahan organik. Hal tersebut sesuai dengan pendapat Ignatius, dkk (2014) semakin banyak dosis pupuk cair yang diberikan dapat semakin meningkatkan panjang buah, diameter buah, jumlah buah dan berat buah tanaman terung.

Kondisi C-Organik pada lahan penelitian yang rendah yaitu 1,332 \% mengindikasikan jumlah mikroba dalam tanah sangat sedikit. Pemberian POC buah pepaya diduga dapat menambahkan mikroba dalam tanah. Mikroba yang terkandung dalam POC buah pepaya dapat memperbaiki kondisi unsur $\mathrm{P}$ dan $\mathrm{K}$ dalam tanah penelitian yang tergolong sangat rendah yaitu (1,858 dan 3,230) ppm. Unsur P dan K akan merangsang penyebaran akar tanaman dan memiliki fungsi dalam memperbaiki mutu dan meningkatkan hasil berupa buah. Maka dari itu dalam pembentukan bunga dan buah sangat diperlukan pasokan P yang cukup (Agustina, 1990). 
Jumlah buah pada tanaman mentimun sangat berhubungan dengan jumlah bunga betina yang terbentuk dan terjadi penyerbukan serta tidak mengalami gugur buah. Pada fase ini tanaman memerlukan unsur kalium yang cukup. Dengan tersedianya mikroba dalam tanah tanaman dapat dengan mudah menyerap unsur hara dalam tanah. Tufaila (2014) menyatakan bahwa, kalium berperan penting bagi tanaman mentimun, fungsi utamanya yaitu membantu pembentukan protein dan karbohidrat. Kalium juga memperkuat tubuh tanaman agar daun, bunga dan buah tidak mudah gugur.

\section{Jumlah Buah Mentimun Per Plot}

Hasil analisis ragam perlakuan dosis POC buah pepaya berpengaruh sangat nyata pada variabel pengamatan jumlah buah per plot mentimun dapat dilihat pada. Perlakuan yang memberikan pengaruh nyata atau sangat nyata maka dilanjutkan dengan uji jarak berganda Duncan (Tabel 5).

Tabel 5. Pengaruh dosis POC buah Pepaya terhadap jumlah buah per plot tanaman mentimun.

\begin{tabular}{cc}
\hline Dosis POC & Rata-Rata Jumlah Buah Per Plot \\
\hline (P0) Tanpa POC Pepaya & $81,67 \mathrm{~d}$ \\
(P1) POC Pepaya dosis $10 \mathrm{ml} / 1$ Air & $82,00 \mathrm{~d}$ \\
(P2) POC Pepaya dosis $20 \mathrm{ml} / 1$ Air & $90,00 \mathrm{~cd}$ \\
(P3) POC Pepaya dosis 30 ml/1 Air & $87,00 \mathrm{~d}$ \\
(P4) POC Pepaya dosis $40 \mathrm{ml} / 1$ Air & $90,67 \mathrm{~cd}$ \\
(P5) POC Pepaya dosis $50 \mathrm{ml} / 1$ Air & $97,33 \mathrm{bcd}$ \\
(P6) POC Pepaya dosis $60 \mathrm{ml} / 1$ Air & $105,0 \mathrm{abc}$ \\
(P7) POC Pepaya dosis $70 \mathrm{ml} / 1$ Air & $98,67 \mathrm{bcd}$ \\
(P8) POC Pepaya dosis $80 \mathrm{ml} / 1$ Air & $109,3 \mathrm{ab}$ \\
(P9) POC Pepaya dosis $90 \mathrm{ml} / 1$ Air & $118,0 \mathrm{a}$ \\
\hline
\end{tabular}

Keterangan : Angka-angka yang diikuti huruf sama menunjukkan tidak berbeda nyata pada Uji jarak berganda Duncan taraf 5\%

Berdasarkan tabel 5, hasil uji jarak berganda Duncan taraf 5\% terhadap variabel pengamatan jumlah buah per plot menunjukkan bahwa perlakuan P3 (pemberian POC buah pepaya dosis $30 \mathrm{ml} / \mathrm{l}$ air) sangat berbeda nyata dengan perlakuan P9 (pemberian POC buah pepaya dosis $90 \mathrm{ml} / \mathrm{l}$ air) , P8 (pemberian POC buah pepaya dosis $80 \mathrm{ml} / \mathrm{l}$ air) dan P6 (pemberian MOL buah pepaya dosis $60 \mathrm{ml} / \mathrm{l}$ air), tetapi tidak berbeda nyata dengan perlakuan lainnya. Sedangkan P9 (pemberian POC buah pepaya dosis $90 \mathrm{ml} / \mathrm{l}$ air) tidak berbeda nyata dengan perlakuan P6 (pemberian POC buah pepaya dosis $60 \mathrm{ml} / \mathrm{l}$ air) dan P8 (pemberian POC buah pepaya dosis $80 \mathrm{ml} / \mathrm{l}$ air), tetapi sangat berbeda nyata dengan perlakuan lainnya. Hasil rata-rata jumlah buah terbanyak per plot dihasilkan pada perlakuan P9 (pemberian POC buah pepaya dosis $90 \mathrm{ml} / \mathrm{l}$ air) dengan jumlah buah 118 buah.

Unsur hara sangat mempengaruhi pertumbuhan dan produktivitas tanaman. Dengan unsur hara yang cukup tanaman akan dapat bertumbuh dengan maksimal. 
Mikroba yang terkandung dalam POC buah pepaya dapat meningkatkan penguraian bahan organik didalam tanah sehingga menjadi tersedia dan mudah diserap tanaman mentimun. Menurut Zulyana (2011), ketersediaan unsur hara yang baik bagi tanaman akan memperlancar fotosintesis. Fotosintesis akan menghasilkan fotosintat yang digunakan untuk pembentukan bunga, biji dan buah.

Meskipun jumlah buah berkaitan erat dengan jumlah bunga betina, namun keterkaitan jumlah buah dengan bunga betina tidaklah mutlak, karena selama masa perkembangan bunga menjadi buah banyak faktor yang mmenghalangi terbentuknya menjadi buah. Gagalnya pembentukan buah dari suatu tanaman disebabkan oleh ekologi (suhu, angin, kelembapan, dan sebagainya), unsur hara yang tidak seimbang (terutama $\mathrm{N}$, $\mathrm{P}$ dan $\mathrm{K}$ ), air berlebihan atau kekurangan air, gangguan hama dan penyakit (Sunarjono, 2004).

\section{Berat Buah Mentimun Per Tanaman (g)}

Hasil analisis ragam perlakuan dosis POC buah pepaya berpengaruh sangat nyata pada variabel pengamatan berat buah mentimun per tanaman. Perlakuan yang memberikan pengaruh nyata atau sangat nyata maka dilanjutkan dengan uji jarak berganda Duncan (Tabel 6).

Tabel 6. Pengaruh dosis POC buah Pepaya terhadap berat buah mentimun per tanaman.

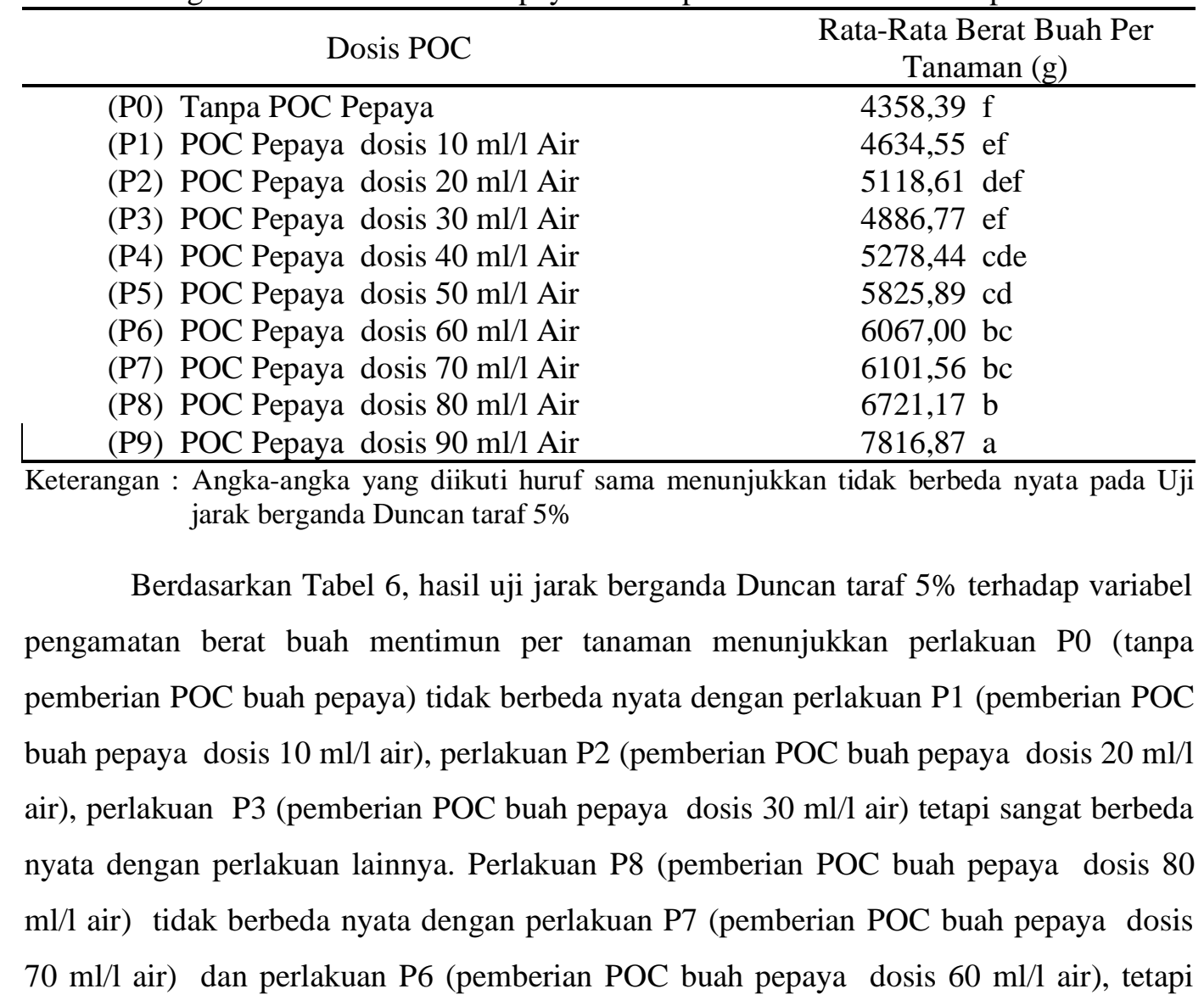


sangat berbeda nyata dengan perlakuan lainnya. Sedangkan perlakuan P9 (pemberian POC buah pepaya dosis $90 \mathrm{ml} / \mathrm{l}$ air) sangat berbeda nyata dengan perlakuan lainnya.Hasil rata-rata berat buah per tanaman terbaik didapat pada perlakuan P9 yaitu 7816,87 gram. Hal ini diduga mikroba yang terkandung dalam POC buah pepaya meningkatkan penguraian bahan organik didalam tanah sehingga menjadi tersedia bagi tanaman mentimun.

Produktivitas tanaman dipengaruhi oleh pertumbuhan vegetatifnya. Jika pertumbuhan vegetatif baik maka kemungkinan pertumbuhan generatifnya akan baik pula. Dengan tersedianya mikroba dalam tanah tanaman akan lebih mudah untuk mendapatkan unsur hara yang dibutuhkan seperti N, P dan K. Djunaedy (2009) menyatakan bahwa, Fotosintat yang dihasilkan oleh tanaman selain digunakan untuk pertumbuhan dan perkembangan juga disimpan oleh tanaman sebagai cadangan makanan. Fotosintat yang terdapat dalam daun diangkut keseluruh tubuh tanaman, yaitu bagianbagian meristem dititik tumbuh dan ke buah yang sedang dalam perkembangan. Jika fotosintesis yang dilakukan oleh tanaman dapat berlangsung dengan optimal maka fotosintat yang dihasilkan akan maksimal juga, yang akhirnya akan berpengaruh pada ukuran dan berat buah.

Pada pertumbuhan generatif tanaman memerlukan pasokan unsur $\mathrm{P}$ dan $\mathrm{K}$ yang cukup. Bakteri pelarut fosfat yang terkandung dalam POC pepaya merubah fosfat tidak larut dalam tanah menjadi bentuk yang dapat larut dan mudah diserap tanaman dengan mensekresikan asam organik seperti asam folat, asetat, propionat, laktat, glikolat, fumarat dan suksinat (Suliasih, 2006). Lingga dan Marsono (2007), berpendapat pada fase generatif berat buah tidak lepas dari peranan unsur hara yang terdapat pada tanah. Pada fase ini unsur hara makro P dan K berperan aktif.

\section{Berat Buah Mentimun Per Plot (g)}

Hasil analisis ragam menunjukkan perlakuan dosis POC buah pepaya berpengaruh sangat nyata pada variabel pengamatan berat buah mentimun per plot . Perlakuan yang memberikan pengaruh nyata atau sangat nyata maka dilanjutkan dengan uji jarak berganda Duncan (Tabel 7).

Berdasarkan Tabel 7, hasil uji jarak berganda Duncan taraf 5\% terhadap variabel pengamatan berat buah mentimun per plot menunjukkan bahwa perlakuan P0 (tanpa pemberian POC buah pepaya) tidak berbeda nyata dengan perlakuan P1 (pemberian POC buah pepaya dosis $10 \mathrm{ml} / \mathrm{l}$ air), perlakuan P2 (pemberian POC buah pepaya dosis $20 \mathrm{ml} / \mathrm{l}$ air), perlakuan $\mathrm{P} 3$ (pemberian $\mathrm{POC}$ buah pepaya dosis $30 \mathrm{ml} / \mathrm{l}$ air) tetapi sangat berbeda nyata dengan perlakuan lainnya. Perlakuan P8 (pemberian POC buah pepaya dosis 80 
$\mathrm{ml} / \mathrm{l}$ air) tidak berbeda nyata dengan perlakuan P7 (pemberian POC pepaya dosis $70 \mathrm{ml} / \mathrm{l}$ air) dan perlakuan P6 (pemberian POC buah pepaya dosis $60 \mathrm{ml} / \mathrm{l}$ air), tetapi sangat berbeda nyata dengan perlakuan lainnya. Sedangkan perlakuan P9 (pemberian POC buah pepaya dosis $90 \mathrm{ml} / \mathrm{l}$ air) sangat berbeda nyata dengan perlakuan lainnya. Rata-rata berat buah per plot terbaik dihasilkan pada perlakuan P9 (pemberian POC buah pepaya dosis $90 \mathrm{ml} / \mathrm{l}$ air) yaitu 46900,67 g.

Tabel 7. Pengaruh dosis POC buah Pepaya terhadap berat buah per plot tanaman mentimun.

\begin{tabular}{cc}
\hline \multicolumn{1}{c}{ Dosis POC } & $\begin{array}{c}\text { Rata-Rata Berat Buah Per Plot } \\
(\mathrm{g})\end{array}$ \\
\hline (P0) Tanpa POC Pepaya & $26150,33 \mathrm{f}$ \\
(P1) POC Pepaya dosis $10 \mathrm{ml} / 1$ Air & $27753,33 \mathrm{ef}$ \\
(P2) POC Pepaya dosis $20 \mathrm{ml} / 1$ Air & $30711,67 \mathrm{def}$ \\
(P3) POC Pepaya dosis 30 ml/1 Air & $29320,67 \mathrm{ef}$ \\
(P4) POC Pepaya dosis 40 ml/1 Air & $31670,67 \mathrm{cde}$ \\
(P5) POC Pepaya dosis 50 ml/1 Air & $34955,33 \mathrm{~cd}$ \\
(P6) POC Pepaya dosis $60 \mathrm{ml} / 1$ Air & $36402,00 \mathrm{bc}$ \\
(P7) POC Pepaya dosis 70 ml/1 Air & $36609,33 \mathrm{bc}$ \\
(P8) POC Pepaya dosis $80 \mathrm{ml} / 1$ Air & $40327,00 \mathrm{~b}$ \\
(P9) POC Pepaya dosis 90 ml/1 Air & $46900,67 \mathrm{a}$ \\
\hline Keterangan : Angka-angka yang diikuti huruf sama menunjukkan tidak berbeda nyata pada Uji \\
jarak berganda Duncan taraf 5\%.
\end{tabular}

Hal ini diduga mikroba yang terkandung dalam POC buah pepaya meningkatkan penguraian bahan organik di dalam tanah, sehingga unsur hara menjadi tersedia bagi tanaman mentimun. Simanungkalit (2006) menyatakan, Mikroba tanah berfungsi sebagai penambat unsur hara atau memfasilitasi tersedianya hara dalam tanah bagi tanaman. Bakteri penambat nitrogen, bakteri pelarut fosfat, serta bakteri perombak bahan organik mampu menambat unsur hara yang dibutuhkan oleh tanaman seperti N, P dan K (Habib, dkk. 2017).

Dalam perkembangan generatif unsur $\mathrm{N}, \mathrm{P}$, dan $\mathrm{K}$ sangat dibutuhkan tanaman. Nitrogen berfungsi untuk menjaga daun supaya tidak gugur agar proses fotosintesis terus berlangsung semakin banyak daun yang mengalami fotosintesis, maka fotosintat di dalam biji semakin banyak sehingga ukuran buah semakin meningkat (Dachlan, dkk. 2012). Unsur $\mathrm{P}$ berpengaruh terhadap perangsangan pembungaan dan pembuahan. Sedangkan unsur $\mathrm{K}$ merupakan unsur yang paling berpengaruh terhadap perkembangan buah karena unsur $\mathrm{K}$ dapat diserap dalam bentuk ion $\mathrm{K}^{+}$. Unsur hara $\mathrm{K}$ berfungsi dalam pengangkutan karbohidrat, sebagai katalisator pembentukan protein, meningkatkan kadar karbohidrat dan gula dalam buah, membuat biji lebih berisi dan padat serta buah ukurannya bertambah besar (Wardani, dkk. 2014) 


\section{Berat Berangkasan Basah Tanaman Mentimun (g)}

Hasil analisis ragam perlakuan dosis MOL buah pepaya tidak berpengaruh nyata pada variabel pengamatan berat berangkasan basah tanaman mentimun dapat dilihat pada Gambar 2.

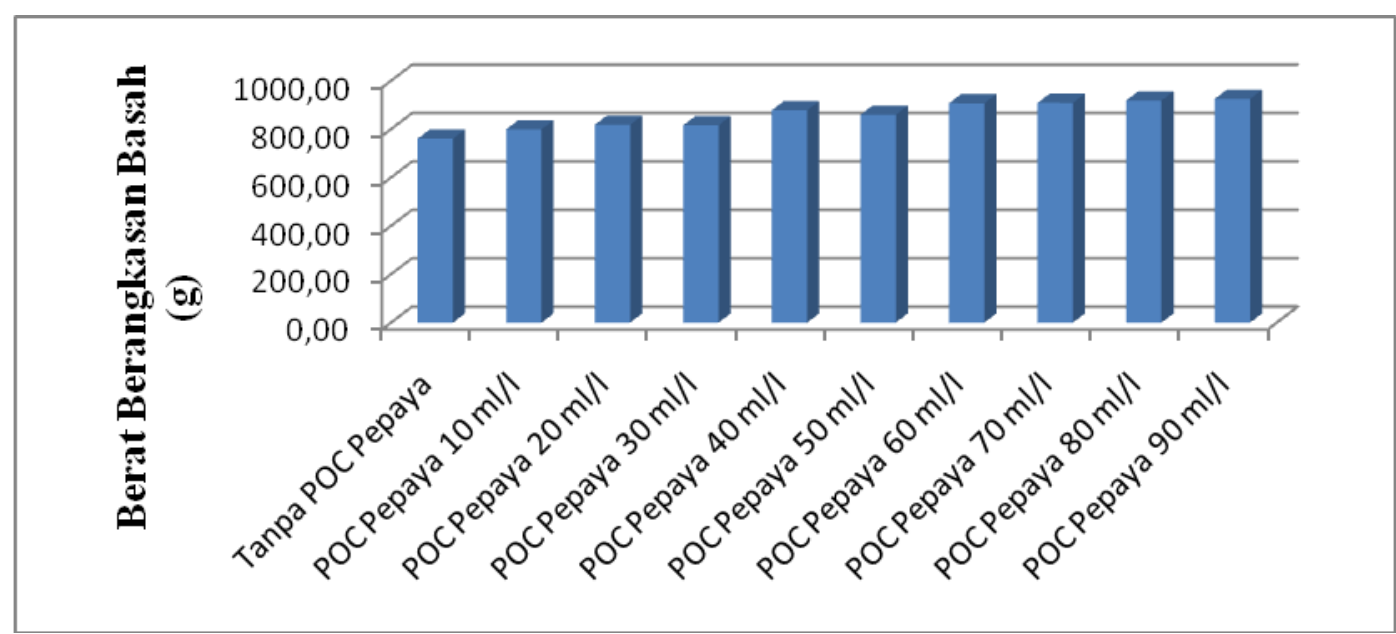

Gambar 2. Pengaruh perlakuan dosis POC buah pepaya terhadap variabel pengamatan berat berangkasan basah tanaman mentimun.

Pemberian POC buah pepaya tidak berpengaruh nyata terhadap variabel pengamatan berat berangkasan basah tanaman mentimun. Perlakuan yang memberikan rata-rata tertinggi yaitu pada perlakuan P9 (pemberian POC buah pepaya dosis $90 \mathrm{ml} / \mathrm{l}$ air) 924,78 gram. Hal ini diduga, unsur hara yang diperlukan tanaman sudah tersedia, dimana mikroorganisme yang terkandung dalam POC buah pepaya mampu menyediakan unsur hara bagi tanaman.

Berat berangkasan basah merupakan cerminan dari aktivitas metabolisme selama masa pertumbuhan tanaman. Pada parameter berat berangkasan basah tidak menunjukkan pebedaan yang nyata akan tetapi semakin tinggi dosis MOL pepaya semakin tinggi pula berat berangkasan basahnya. Hal ini dikarenakan pada dosis yang tinggi terkandung mikroorganisme yang lebih banyak sehingga unsur hara yang diuraikan dan diserap tanaman mentimun semakin banyak pula. Tanaman mentimun merupakan tanaman yang memiliki kadar air tinggi baik buah maupun tanaman. Untuk kadar air tanaman sekitar 79-84\% .Berat berangkasan basah dipengaruhi oleh kadar air dan kandungan unsur hara yang ada dalam sel-sel jaringan, semakin tinggi serapan air dan unsur hara maka bobot berangkasan basah akan meningkat (Wijaya, dkk. 2015)

Hal ini didukung oleh pendapat Subantoro, dkk (2007) dalam penelitiannya menyatakan bahwa meningkatnya penyerapan akar terhadap unsur hara maka proses pertumbuhan tanaman alfalfa mengalami peningkatan dengan cara melihat laju asimilasi berupa parameter pengamatan berat berangkasan basah tanaman. 


\section{Berat Berangkasan Kering Tanaman Mentimun (g)}

Hasil analisis ragam perlakuan dosis POC buah pepaya tidak berpengaruh nyata pada variabel pengamatan berat berangkasan kering tanaman mentimun dapat dilihat pada Gambar 3.

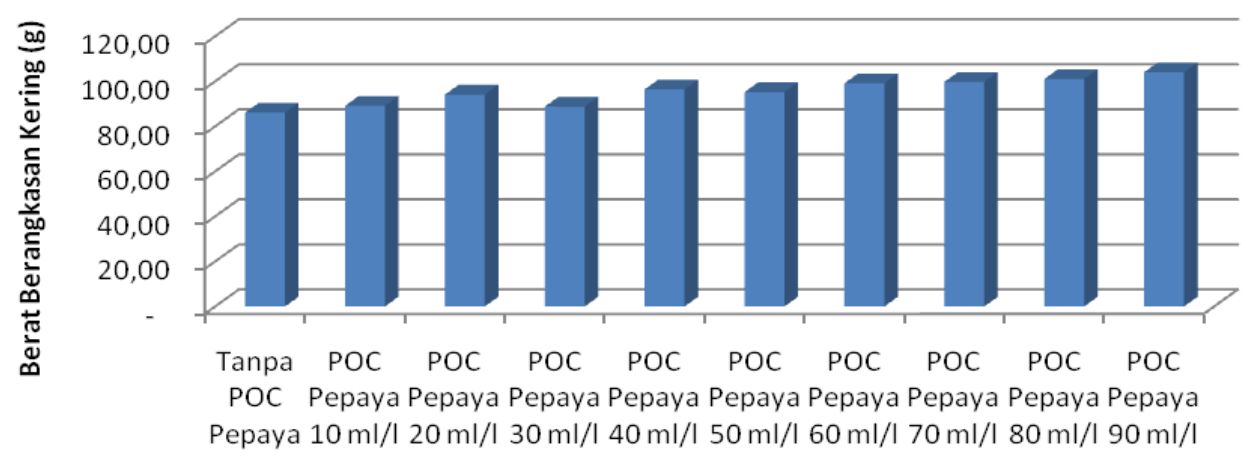

Gambar 3. Pengaruh perlakuan dosis POC buah pepaya terhadap variabel pengamatan berat berangkasan kering tanaman mentimun.

Pemberian POC buah pepaya tidak berpengaruh nyata terhadap variabel pengamatan berat berangkasan kering tanaman mentimun. Perlakuan yang memberikan rata-rata tertinggi yaitu pada perlakuan P9 (pemberian POC buah pepaya dosis $90 \mathrm{ml} / \mathrm{l}$ air) 104,06 gram. Hal ini diduga karena dengan pemberian POC buah pepaya mikroba dalam tanah meningkat sehingga kebutuhan unsur hara tanaman tercukupi.

Berat berangkasan kering tanaman mencerminkan banyaknya unsur hara yang diserap oleh tanaman serta laju fotosintesis. Bustami (2012) menyatakan bahwa, unsur hara pada tanaman berperan dalam proses metabolisme tanaman untuk memproduksi bahan kering yang tergantung pada laju fotosintesis. Bila laju fotosintesis tinggi maka jumlah fotosintat yang dihasilkan juga tinggi demikian juga dengan berat kering tanaman yang merupakan cerminan dari laju pertumbuhan. Hal ini sesuai diperkuat dengan pendapat Wijaya (2015) dalam penelitiannya, Semakin tinggi serapan hara N, P dan K maka akan semakin tinggi pula bobot berangkasan tanaman mentimun. Hal ini karena adanya hubungan erat antara kadar $\mathrm{N}, \mathrm{P}$ dan $\mathrm{K}$ dengan bobot berangkasan tanaman mentimun.

\section{KESIMPULAN}

Berdasarkan hasil penelitian dan pembahasan tentang Efikasi Pupuk Organik Cair (POC) Buah Pepaya terhadap Produktivitas Tanaman Mentimun (Cucumis sativus L.), maka dapat disimpulkan bahwa : 
1. Perlakuan dosis POC buah pepaya tidak berpengaruh terhadap pertumbuhan tanaman mentimun, kecuali pada parameter tinggi tanaman 14 hst. Hasil tertinggi pada dosis POC buah pepaya $90 \mathrm{ml} / \mathrm{l}$ air.

2. Pelakuan dosis POC buah pepaya berpengaruh terhadap produktivitas tanaman mentimun, yaitu pada parameter panjang buah, diameter buah, jumlah buah per tanaman, jumlah buah per plot, berat buah per tanaman dan berat buah per plot. Hasil tertinggi pada setiap parameter didapatkan pada dosis POC buah pepaya 90 $\mathrm{ml} / \mathrm{l}$ air.

\section{DAFTAR PUSTAKA}

Agustina. 1990. Nutrisi Tanaman. Rineka Cipta. Jakarta.

Arinong, A. R., Vandalisna., Dan Asni. 2014. Pertumbuhan dan Produksi Tanaman Sawi (Brassica juncea L.) dengan Pemberian Mikroorganisme lokal (MOL) dan Pupuk Kandang Ayam. Jurnal Agrisistem. 10(1): 40-46.

Badan Pusat Statistik. 2014. Data Produksi Timun Tahun 2010-2014. http://www.bps.go.id/tnmn_pgn.php?kat=3\&id_subyek=53\&notab=0. Diakses Pada Tanggal 15 Oktober 2018

Djunaedy, A. 2009. Pengaruh Jenis dan Dosis Pupuk Bokashi Terhadap Pertumbuhan dan Hasil Kacang Panjang (Vigna sinensis L.) Jurnal Agrovigor. 2(1): 42-46.

Fitriatin, B. N., Anny, Y., Oviyanti, M., Feni, S. F \& Mohamad, D. T. 2009. Pengaruh Mikroba Pelarut Fosfat dan Pupuk P terhadap P Tersedia, Aktivitas Fosfatase, P Tanaman dan Hasil Padi Gogo (Oryza sativa L.) pada Tanah Ultisol. Jurnal Agrikultura. 20(3): 2009.

Habib, I. M. A., Dwi, S. S., \& Lila, M. 2017. Potensi Mikroba Tanah untuk Meningkatkan Pertumbuhan dan Hasil Tanaman Cabai Rawit (Capcisum frutescens L.). Jurnal Folium. 1(1): 28-36.

Husnaeni, R. \& Mieke, R. S. 2018. Pengaruh Pupuk Hayati dan Anorganik Terhadap populasi Azotobacter Kandungan N, dan Hasil Pakcoy Pada Sistem NUTRIENT FILM TECHNIQUE. Jurnal Biodjati. 3(1):90-98.

Ignatius, H. Irianto. \& Ahmad, R. 2014. Respon Tanaman Terung (Solanum melongena L.) Terhadap Pemberian Pupuk Organik Cair Urine Sapi. Jurnal Penelitian Universitas Jambi. 16(1): 31-38.

Lingga, P dan Marsono. 2003. Petunjuk Penggunaan Pupuk. Penebar Swadaya. Jakarta. $93 \mathrm{hlm}$.

Maida, E. 2013. Sistem Intensifikasi Tanaman Padi SRI Melalui Pemanfaatan Mikroorganisme Lokal dalam Pembuatan Kompos dapat Meningkatkan Populasi Mikroba Tanah. Jurnal Agrium. 10(2): 56-60.

Musnamar. 2003. Pupuk Organik: Cair \& Padat, Pembuatan, Aplikasi. Penebar Swadaya. Jakarta.

Oktaviana, Z., Ashari, S., \& Purnamaningsih, S. L. (2016). Pengaruh Perbedaan Umur Masak Benih Terhadap Hasil Panen Tiga Varietas Lokal Mentimun (Cucumis sativus L.). Jurnal Produksi Tanaman. 4(3). 15. 
Purwasasmita, M. 2009. Mikroorganisme Lokal Sebagai Pemicu Siklus Kehidupan dalam Bioreaktor Tanaman. Seminar Nasional Teknik Kimia Indonesia-SNTKI 2009. Bandung 19-20 Oktober 2009.

Simanungkalit, R. Saraswati, D. M. R Hastuti, R. D. \& Husen, E. 2006. Bakteri Penambat Nitrogen. Bogor: Balai Besar Penelitian dan Pengembangan Sumberdaya Lahan Pertanian.

Suketi, K., Roedhy, P., Sriani, S., Sobir., \& Winarso, D. W. 2010. Studi Karakter Mutu Buah Pepaya IPB. J. Hort. Indonesia 1(1): 17-26

Suliasih. Widawati, S. 2006. Populasi Bakteri Pelarut Fosfat (BPF) di Cikaniki, Gunung Botol, dan Ciptarasa serta Kemampuannya melarutkan $\mathrm{P}$ terikat di Media Pikovskaya Padat. Jurnal Biodiversitas. 7(2): 109-113.

Sunarjono, H. H. 2007. Bertanam 30 Jenis Sayuran. Penebar Swadaya, Jakarta. 184 hlm.

Syahputriani, N. 2017. Pengujian Pupuk Organik Cair Limbah Buah Pepaya Pada Pertumbuhan dan Produksi Tanaman Jagung (Zea mays L.) Skripsi. Fakultas Pertanian Universitas Medan.

Tufaila, M. Laksana, D. D. \& Alam, S. 2014. Aplikasi Kompos Kotoran Ayam untuk Meningkatkan Hasil Tanaman Mentimun (Cucumis sativus L.) di Tanah Masam. Jurnal Agroteknos. 4(2): 119-126.

Widyati, E. 2013. Memahami Interaksi Tanaman - Mikroba. Tekno Hutan Tanaman. Jurnal Hutan Tanaman. 6(1):13-20.

Wijaya, A. A., Jamalam, L \& Yohanes, C. G. 2015. Uji Efektivitas Pupuk Organonitrofos dan Kombinasinya dengan Pupuk Anorganik Terhadap Pertumbuhan, Serapan Hara dan Produksi Tanaman Mentimun (Cucumis sativus L.) pada Musim Tanam Kedua di Tanah Ultisol Gedung Meneng. Jurnal Agrotek Tropika. 3(3): 409-421.

Yadi, S., Karimuna, L., \& Laode, S. 2012. Pengaruh Pemangkasan dan Pemberian Pupuk Organik Terhadap Produksi Tanaman Mentimun (Cucumis sativus L.). Jurnal Penelitian Agronomi. 1(2): 107-114.

Zulyana, U. 2011. Respon Ketimun (Cucumis sativus L.) terhadap Pemberian Kombinasi Dosis dan Macam Bentuk Kotoran Sapi di Getasan. Skripsi. Universitas 